\title{
FACTORS INFLUENCING READMISSION TO HOSPITAL
}

\section{TETRAPLEGIA}

\author{
By I. G. Burnside, M.A., M.Sc., Senior Clinical Psychologist and \\ J. B. Cook, M.D., F.R.C.P., Consultant Neurologist \\ Yorkshire Regional Spinal Injuries Unit, Centre for Neurology, Neurosurgery and Neuro- \\ logical Trauma, Pinderfields Hospital, Wakefield, England
}

Abstract. Tetraplegia produces exceptionally severe physical impairment causing disability which demands almost total dependence on others for the activities of daily living but there is no impairment of mental function. The tetraplegic is, therefore, capable of influencing his environment and those features of it which may lead to the need for readmission to hospital. Of the factors studied relating to readmission to hospital, only age and occupational status of the patient at the time of his paralysis are of significance.

Key words: Readmission, Tetraplegia, Occupation.

\section{Introduction}

THE almost total immobility, loss of cutaneous sensation and loss of sphincter control in the tetraplegic make him vulnerable to respiratory infection, skin ulceration and to urinary complications which may give rise to recurrent ill health demanding readmission to hospital. These complications of tetraplegia may to a large extent be prevented by adherence to rules of care and hygiene which although basically simple, are arduous in their execution, demanding upon those caring for the tetraplegic and requiring basic environmental standards. Although all tetraplegics are vulnerable in this way, there are some who are readmitted to hospital more frequently than others and this investigation was undertaken to find out the factors which determine readmission to hospital of the tetraplegic patient.

\section{Material and Methods}

Patients with cervical spinal cord paralysis admitted for the first time to the Yorkshire Regional Spinal Injuries Unit, were reviewed over a Io-year period. Those who died during the first admission to hospital and those who had already lived in the community as tetraplegics before their first admission to the unit were excluded. Of 97 tetraplegics, information on occupational status was incomplete in 27 , who were therefore excluded from the investigation. A comparison of the 70 patients included and the 27 with incomplete information, showed that there was no statistical difference in age, number of readmissions or severity of disability. Because the deficiency of information in the group of 27 concerned occupational status, it is not surprising that there was a statistically significant larger number of females than in the group of $70\left(\chi^{2}=13.34\right.$, d.f. $\left.=\mathrm{I}, \mathrm{P}=0.0 \mathrm{I}\right)$. However, in the total of 97 tetraplegics there was no significant relationship between the sex of the patient and readmission. The investigation, therefore, proceeded on the 70 tetraplegics for whom complete information was available. 
Of the 70 tetraplegic patients included, there were 6I male and 9 female, with an age range of from 16 to 75 years. The incidence of tetraplegia by age was as follows:

$\begin{array}{ll}\text { Under } 30 \text { years of age } & 25 \\ 30-50 \text { years of age } & \text { I6 } \\ \text { Over 50 years of age } & 29\end{array}$

Whether the cord lesion was complete or incomplete was assessed on a functional basis, those having some voluntary movement below the level of the lesion being classified as partial. All suffered bladder and bowel disfunction. By these criteria 47 were considered complete and 23 incomplete.

The occupation of the tetraplegic at the time of his becoming paralysed was classified according to the document 'Classification of Occupations 1970' of the Office of Population Censuses and Surveys. For the convenience of the study the categories given in that document were grouped into four as follows:

$\begin{array}{ll}\text { Category II and IIIN } & \text { non-manual } \\ \text { Category IIIM } & \text { skilled manual } \\ \text { Category IV } & \text { partially skilled manual } \\ \text { Category V } & \text { unskilled manual }\end{array}$

The unit records were scrutinised to determine the number of readmissions to hospital of every tetraplegic. Because the unit has a policy of brief readmission for routine urological survey, readmission for 24 hours or less was excluded.

The tetraplegic patients were admitted from a wide area of the north of England, not confined to the Yorkshire Regional Health Authority. The area contains a large, heavily populated industrial, urban community and a more widely dispersed rural community.

The occupational status of the 70 tetraplegic patients was as follows:

$\begin{array}{ll}\text { Non-manual } & \text { I7 } \\ \text { Skilled manual } & 27 \\ \text { Partially skilled manual } & \text { I4 } \\ \text { Unskilled manual } & \text { I2 }\end{array}$

\section{Results}

The data were analysed according to the $\chi^{2}$ test described by Siegel (I956). Because most patients were not readmitted, the data were skewed. Therefore, the analyses compared those not readmitted with those having one or more readmissions.

The readmission rate of 70 patients with cervical spinal cord damage showed no relationship to whether the lesion was partial or complete $\left(\chi^{2}=3.42\right.$, d.f. $=\mathrm{I}$, $\mathrm{P}=$ N.S.).

Consideration of age appeared to indicate that those under 30 had a higher readmission rate than those over 30 years of age and this was confirmed statistically $\left(\chi^{2}=\mathrm{I} 6 \cdot 6\right.$, d.f. $\left.=2, \mathrm{P}=0.00 \mathrm{I}\right)$. A further analysis using the method of Cochran (I954) showed that there was a linear regression of readmission rate on age $(\mathrm{P}=0.00 \mathrm{I})$. The younger the patient, the greater the number of readmissions.

There was a statistically significant relationship between readmission rate and occupational status at the time of becoming paralysed $\left(\chi^{2}=12.5\right.$, d.f. $=3$, $\mathrm{P}=0.005)$. There was a linear regression of readmission rate on social class $(P=0.0 I)$, indicating that the lower the occupational status at the time of the $14 / 3-D$ 


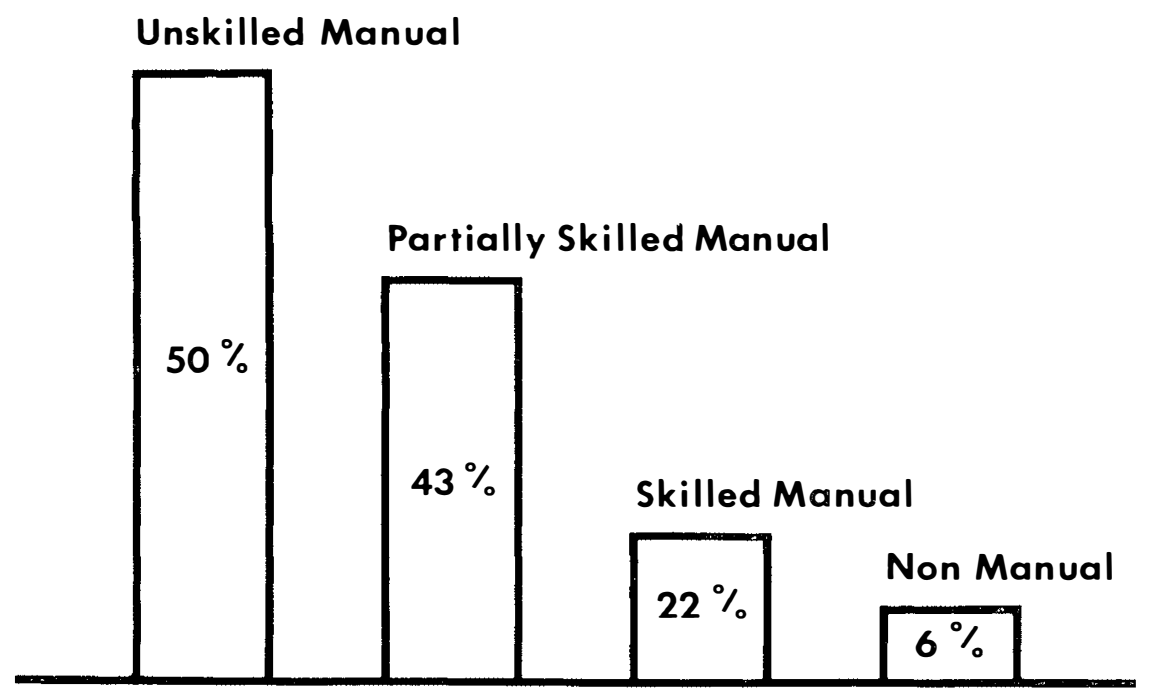

FIG. I

Percentage in each group having one or more readmissions.

accident, the greater is the likelihood of readmission to hospital. This relationship may be demonstrated from the percentage in each group having one or more readmissions (fig. I).

In order to determine whether the effect of occupational status upon the readmission rate might possibly be due to the effect of age, a further $\chi^{2}$ analysis was undertaken which showed no relationship between age and occupational status $\left(\chi^{2}=3.7\right.$, d.f. $=6, P=$ N.S. $)$. To establish that there could be no relationship between the powers of recovery, social class and age, an analysis was made of the duration of initial admission to hospital immediately following paralysis and it was found that of all the factors which have been studied, it was only the severity of the spinal cord damage which was related to duration of initial admission $\left(\chi^{2}=4.9\right.$, d.f. $\left.=\mathrm{I}, \mathrm{P}=0.05\right)$.

\section{Discussion}

The prevention of ill health in the tetraplegic patient is so dependent upon strict adherence to simple but very demanding rules of care and hygiene and the burden upon relatives and friends so great, that readmission to hospital may be determined by the intelligence, personality and natural inclinations of the patient and those who care for him. Little work has been done upon the relationship between intelligence and health in the tetraplegic patient. Cull and Smith (1973) studied the relationship between the incidence of decubitus ulcer and intelligence in I 44 cord injured 'students' and found that there was no relationship. They do not, however, give details of the results of their investigation and it is possible that they were dealing with a group of students, all falling within a pre-selected range of intelligence.

It may be of significance that practically the only functions spared in tetraplegia are the ability of the tetraplegic himself to reason and to exert his personality. 
Thereby his life style after paralysis is likely to follow that which existed before his accident, which in turn may influence his ability to exist in the community without being dependent upon hospital in-patient care.

The results of this investigation show that of the factors studied, it is only age and the occupational status of the patient that are related to readmission to hospital and it tends to confirm the view that problems of rehabilitation bear little relationship to the extent or severity of disability. In this study there was no relationship between readmission and whether the paralysis was complete or incomplete.

The health and community services are greatly concerned for the elderly, to the extent that the care of the elderly is being given special consideration, but rather surprisingly, the results of this study suggest that in tetraplegia, it is the age-group under 30 who are least able to care for themselves in the community and who most frequently require hospital readmission. Although the tetraplegics included in the trial were drawn from an area which includes very heavy industry, including coal mining, it is of interest that despite the prominence of injury as a cause of tetraplegia, the unskilled and semi-skilled do not show a preponderance. This is reflected in the general reduction in admission of miners to hospital with spinal injury and the increase in admission for injury due to road traffic accidents.

\section{Conclusion}

There are obviously a number of factors involved in the readmission of the tetraplegic to hospital. The results of this study may lead to much speculation of psychological, sociological and even of a political nature. They could be manipulated to justify a variety of dogmata but as in other social trends, they do not provide any ready answers (British Medical fournal, 1976). They are put forward now to indicate no more than that the problems of tetraplegia in the community relate to the tetraplegic as a person rather than to the nature or extent of his injury.

\section{RÉSUMÉ}

La tetraplegie produit exceptionnellement un sévère dérangement physique, causant une incapacité que demande presque une dépendance totale sur les autres pour les activités de la vie quotidienne, mais il n' y a pas un dérangement de la fonction mentale. Le tetraplégique est aussi capable d'influencer son environ, dont les aspects peuvent conduire au besoin de sa ré-admission à l'hopital.

De tous les facteurs étudiés qui se rapportent a la ré'admission à l'hopital, l'age et l'état d'occupation du malade au temps le sa paralysie semblent être seulement les plus significants.

\section{ZUSAMMENFASSUNG}

Die Tetraplegie ruft ausserordentlich schwere körperliche Schädigung hervor, die eine Unfähigkeit verursacht, welche fast totale Abhängigkeit auf andere für die Tätigkeiten des Tageslebens verlangt, aber es gibt keine Schädigung des Geistes. Der Tetraplegiker ist also imstande seine Ungebung zu beeinflüssen, auch jene Eigenschaften die zur Not für Wiedereintritt ins Krankenhaus führen könnte. Aus den bekanten Faktoren mit Bezug auf den Wiedereintritt ins Krankenhaus, nur Alter und Berufsstellung [des Patients zur Zeit seiner Lähmung sind von Bedeutung.

Acknowledgement. We thank the Medical Illustration Department, Leeds University (St James's) Hospital for the preparation of Figure I. 


\section{REFERENCES}

British Medical fournal (1976). 'Social trends', I, I78.

Cochran, W. G. (1954). Some methods of strengthening the common chi ${ }^{2}$ tests. Biometrika, ro, 4I 7-45I.

Cull, J. G. \& SMITH, O. J. (1973). A preliminary note of demographic and personality correlates of the decubitus ulcer incidence. F. Psychol. 85, 225-227.

Siegel, S. (1956). Nonparametric Statistics for the Behavioural Sciences. McGraw Hill, New York. 